\title{
第23回 日本血管病理研究会
}

\author{
会期：平成 30 年 11 月 10 日 \\ 会場：海峡メッセ下関 国際貿易ビル8階 \\ 当番世話人：池田栄二（山口大学大学院医学系研究科病理形態学講座）
}

セッションI

座長：宮崎龍彦（岐阜大学医学部附属病院病理部）

\section{I-1. ANCA 陰性小血管炎の一剖検例}

${ }^{1}$ 山口大学大学院医学系研究科 病理形態学講座, ${ }^{2}$ 山口 大学医学部附属病院病理診断科, ${ }^{3}$ 山口大学大学院医学 系研究科 保健学専攻 基礎検査学, ${ }^{4}$ 山口大学大学院 医学系研究科 器官病態内科学, 5 済生会下関総合病院 腎臟内科, ${ }^{6}$ 山口大学医学部附属病院 臨床研修医 仲田成美 ${ }^{1,2}$, 河野裕夫 ${ }^{3}$, 崔 丹 ${ }^{1}$, 筑本愛祐美 ${ }^{6}$, 山 岡孝之 ${ }^{5}$, 池上直慶 ${ }^{4}$, 池田栄二 ${ }^{1}$

【症例】73歳男性。両下腿紫斑を主訴に当院受診し, 白血球破砕性血管炎と診断され，抗ヒスタミン薬の内 服とステロイド外用薬の塗布で皮疹は軽快していた。 数週間後から発熱，全身倦点感が出現し，再診時には CRP上昇していた。MPO-ANCA陰性，PR3-ANCA陰性 であったが，血尿，蛋白尿，腎機能低下を認め，顕微鏡 的多発血管炎が疑われ，入院となった。入院後，各種培 養の結果を待たずにステロイド及び抗菌薬を開始した。 徐々に酸素化不良が見られ， CT で気管支肺炎を疑う所 見を認めたため, 抗菌薬治療を継続した。以降も肺浸 潤影は増悪し続け， CRP, WBC，発熱は数日毎に上昇を 繰り返した。その後, 全身状態増悪し, 呼吸状態が悪化 し，死亡した。【剖検所見】剖検時，腎は一部の糸球体 に半月体形成やメサンギウム基質の増殖を認めた。肺で は様々な時相の肺胞出血, 毛細血管炎の所見が見られ, 器質化像が見られた。腎病変は治療修飾後であるため, 典型的な像とは言えないが, 肺病変と生前の皮虐病理所 見と合わせて，顕微鏡的多発血管炎として矛盾しない所 見であった。なお，中〜大型血管には血管炎の所見は認 めなかった。ANCA 除性小血管炎の剖検例を報告する。
I-2. 肝生検でのみ主要組織所見を満たした好酸球性 多発血管炎性肉芽腫症例

KKR 札幌医療センター 病理診断科

山本朝日，柳内 充，鈴木 昭

\section{I-3. 好酸球性多発血管炎性肉芽腫症の一例}

1 順天堂大学医学部附属練馬病院 病理診断科, ${ }^{2}$ 順天堂 大学医学部附属練馬病院 皮膚・アレルギー科

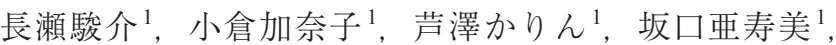
深井達夫 ${ }^{2}$, 松本俊治 $^{1}$

\section{I-4. 小腸穿孔を伴った好酸球性多発血管炎性肉芽腫 症の 1 例}

秋田厚生医療センター 病理診断科 高橋正人

症例 53 歳, 女性。主訴は腹痛, 下痢, 下血。既往歴 は4年前よりアレルギー性鼻炎抢よび気管支喘息。現病 歴は体重減少，腹痛，下㾥，下血を主訴に当院消化器内 科を受診，造影 CTで小腸の壁肥厚を認め小腸炎と診断 された。採血で好酸球増多を認め, MPO-ANCA は陰性。 骨髄生検では好酸球増多による過形成骨髄であったが FIP1L1-PDGFR $\alpha 4 q 12$ 欠損は無く, 慢性好酸球性白血病 は否定的された。気管支鏡生検検体では好酸球性肺炎を 認めた。以上より EGPA と診断され，PSL40mg/日が開始 された。その4日後, 下腹部痛出現， CTで free airを認 め, 消化管穿孔疑いで緊急開腹手術が行われた。小腸部 分切除標本では肉眼的に小腸穿孔と漿膜炎，割面で多発 小結節性病変がみられ，組織像では小腸壁全体に好酸球 浸潤著明な小動脈の壞死性血管炎掞よび，肉芽腫性血管 炎を認め, 両者の移行像もみられた。また，血管外肉芽 腫も多発していた。穿孔は血管炎に伴う局所の循環不全 と考えた。術後経過は良好で, 発症後約半年経過してい るが, 寛解に至り外来経過観察中である。本例は重症度 4 度のEGPA として典型例だと思われたので報告する。 


\section{I-5.TNF阻害薬により舌肉芽腫性血管炎およびアミ ロイド沈着を示した症例}

1 市立札幌病院 病理診断科, 2 苫小牧市立病院 内科, 3 北海道大学大学院 保健科学研究院

岩崎沙理 ${ }^{1}$, 渡辺俊之 ${ }^{2}$, 今本鉄平 ${ }^{1}$, 石立尚路 ${ }^{1}$, 牧田啓 史 $^{1}$, 辻 隆裕 ${ }^{1}$, 深澤雄一郎 ${ }^{1}$, 石津明洋 ${ }^{3}$

【症例】70代男性。【現病歴】 30 代でベーチェット病 と診断，40代より下腿に難治性皮膚潰瘍出現，75歳時 に完全房室ブロックに対し苫小牧市立病院循環器内科 で加療された際，ベーチェット病に対し内科コンサルト された。皮膚潰瘍に対し血管ベーチェットの可能性を 考え, TNF 阻害薬（インフリキシマブ）を導入したとこ ろ，3ケ月後に舌の硬結と疼痛が出現し，腫瘍性疾患が 疑われて舌生検された。TNF 阻害薬休止2 2 月で舌症状 が改善し, 今に至る。【既往歴】結核, 全盲。【組織所 見】舌粘膜下や筋層内に，巣状に炎症を認める。中心に は好酸性無構造なアミロイド沈着があり，血管壁構造の 断裂, 多核巨細胞の浸潤を伴って肉芽腫性血管炎の像を 呈する。【考察】近年, TNF $\alpha$ 阻害薬による血管炎の報 告がなされている。皮膚に多く, 未梢神経や腎臓, 中枢 神経などにも見られ，主として非壊死性血管炎の像を呈 するとされる。本例のように，肉芽腫性血管炎やアミロ イド沈着を伴う症例は稀であり，文献を加えて報告した w。

セッション॥

座長：浅田祐士郎（宮崎大学医学部 病理学講座 構 造機能病態学分野)

\section{II-1. Extracranial giant cell arteritis の 2例}

1 信州大学医学部 病理組織学教室, 2 国立病院機構函館 病院 循環器科, ${ }^{3}$ 国立病院機構函館病院 心臓血管外 科, ${ }^{4}$ 国立病院機構函館病院 病理診断科 里見英俊 ${ }^{1}$, 小室 薰 $^{2}$, 島津 香 $^{2}$, 石川和徳 ${ }^{3}$, 窪田武 浩 $^{3}$, 小林実喜子 ${ }^{1}$, 木村伯子 ${ }^{4}$, 菅野祐幸 ${ }^{1}$

\section{II-2． 胸部大動脈瘤自己弁温存基部置換術後重症心 不全となったMarfan症候群の一例}

1 愛媛大学大学院医学系研究科 解析病理学 · 愛媛大学 プロテオサイエンスセンター 病理学部門, 2 愛媛大学 大学院医学系研究科 循環器 - 呼吸器 - 腎高血圧内科
学, 3 愛媛大学大学院医学系研究科 心臓血管 - 呼吸器 外科学, 4 愛媛大学医学部附属病院 病理部 倉田美恵 ${ }^{1}$, 上谷晃由 ${ }^{2}$, 東 晴彦 $^{2}$, 山口 修 ${ }^{2}$, 泉谷裕 則 $^{3}$, 福島万奈 ${ }^{4}$, 北澤理子 ${ }^{4}$, 増本純也 ${ }^{1}$

Marfan症候群は弾性線維の形成異常や構築異常が生じ る疾患である。心血管病変として大動脈基部拡張と弁膜 症が特徵とされているが, 弁膜症が軽度であっても血行 動態に寄らない心筋症を発症すること，それは心血管系 手術後に増悪することが報告されている。今回私たちは 大動脈置換術後に心不全が急性増悪した症例を経験し た。症例は 3 歳時に水晶体亜脱臼などから Marfan 症候群 と診断された。血縁者にMarfan症候群は診断されてい ない。24歳時に労作時呼吸困難を主訴に当院循環器内 科を受診し, 心エコーと心筋生検から拡張型心筋症と診 断された。以後アンジオテンシン受容体拮抗薬と $\beta$ 遮断 薬で加療されていた。徐々に大動脈弁輪拡大が進行し, 34 歳時に胸部大動脈瘤自己并温存基部置換術（David 術）を受けた。術前心エコーで左室駆出率（EF） 51\%で あったが術後はEF $25 \%$ に低下しカテコラミン依存状態 となった。補助人工心臓（VAD）・心移植の適応となり， $\mathrm{VAD}$ 植込み術を行われた。術中採取された左心室心筋 は配列が乱れ，心筋周囲の線維化が見られた。心筋は不 規則な肥大と菲薄化が混在し核型不整が目立つた。Marfan 症候群の開心術後の心不全急性増悪は非Marfan 症候 群と比して高率とされている。その詳細なメカニズムは 明らかではないものの, 注意すべき病態であり文献的考 察を加え報告する。

\section{II-3. 乳児発症大動脈炎罹患 9 年後に巨大大動脈瘤を 合併した 1 例}

${ }^{1}$ 東京医科歯科大学小児科, ${ }^{2}$ 東京医科歯科大学病理部, 3 東邦大学医療センター大橋病院 病理診断科 前田佳真 ${ }^{1}$, 下山輝義 ${ }^{1}$, 野村知弘 ${ }^{1}$, 長島彩子 ${ }^{1}$, 山口

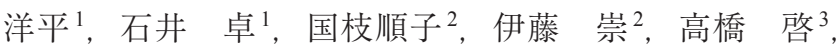
土井庄三郎 ${ }^{1}$

症例は 10 歳女児。家族歴に大動脈瘤解離（母方祖母 と母方叔父）と IgA 腎症（母方叔父と母）を有する。生 後 3 力月で大動脈炎を発症し, 当時は感染性大動脈炎の 診断にて抗菌薬とアスピリンにて治療されたが，大動脈 と肺動脈の壁不整と拡張が残存した。その後 8 歳までア スピリン内服を継続していたが, 大動脈および肺動脈に 大きな変化は認めなかった。9歳時にMRIにて上行大動 
脈から下降大動脈に至る直径 $55 \mathrm{~mm}$ の大動脈瘤を認め, FDG-PETdeha。大動脈瘤に一致してFDGの取り込みを 認めた。本症例は大動脈炎症候群も念頭に入れ, Infliximab投与後に大動脈置換術を無事に施行できた。手術 で得られた大動脈の検体では, 非動脈瘤部の中膜で微小 な平滑筋の脱落と弾性繊維の断裂を認めた。動脈瘤部で は大動脈の基本構造は消失し，一部残存した中膜でも平 滑筋細胞の変性と弾性線維消失が目立った。加えて, 動 脈㢚部の中膜と外膜との境界部を中心とした小血管の増 生が目立ち，炎症細胞浸潤を認めた。本症例と母およ び母方祖母の遺伝子からはSMAD3の mutationを認めて おり，病理所見と合わせて考えると構築異常をもつ大動 脈に炎症を合併したことで大動脈瘤が惹起されたと推測 されるが，その大動脈炎の診断についてご意見を伺いた い。

\section{II-4. 胆囊穿刺を契機に破裂した膵尾部AVMの一例} 岐皁大学医学部附属病院 病理部

宮崎龍彦，小林一博，久松憲治，酒々井夏子，松本宗和

患者は 60 代女性。くも膜下出血で脳外科に入院。コ イル塞栓術施行し経過良好であったが，day11に発熱・ 腹痛 - 失語症状出現。白血球増多と胆道系酵素上昇, 胆 囊腫大，胆砂をみとめたため，胆囊炎を疑い， day12に 胆囊穿刺したところ，穿刺後 2 時間で血圧低下，あえぎ 呼吸が出現。貧血の進行と, $\mathrm{CT}$ 上腹腔内の液体貯留を 認め, 腹腔内出血による出血性ショックと診断, 開腹し 止血術を行った。出血源は膵尾部近傍の下腸間膜静脈で あった。術後の再出血はなかったが，血圧低下により広 範囲の脳梗塞を合併し，腎不全・肝不全もきたしday22 に死亡した。剖検では下行結腸，膵尾部，脾臓に囲まれ る位置に血腫形成と止血綘合部を認めた。組織学的には 不規則な壁を持つ静脈性血管の破綻と縫合痕が観察され ると共に，その周囲に不規則な血管増生を密に認めた。 静脈性血管が大半を占めたが，不規則な走行を示す毛細 血管とともに異常な動脈性血管や，中膜の構造に動脈と 静脈の移行があるようにみえる異常血管も多数認めた。 また，縫合部付近では中膜平滑筋の異常な断裂を認め た。Spasmを契機としたArterio-venous malformationもし くはvenous malformationの破裂による出血と考えている が，腹腔内の vascular malformationの破裂の報告は数え るほどしかなく，診断確定に難渋している。稀少な症例 として報告する。
セッションIII

\section{座長：菅野祐幸（信州大学医学部 病理組織学教室）}

\section{III-1. 抗糸球体基底膜抗体病（抗 GBM病）の頻回再 発症例の抗 GBM が認識するエピトープ}

${ }^{1}$ 北海道大学大学院保健科学研究院 病態解析学分野, 2 北海道大学大学院医学研究院 免疫. 代謝内科学, ${ }^{3}$ 北海道大学 死因究明教育研究センター, ${ }^{4}$ 北海道大学 大学院医学研究院 分子病理学教室, 5 杏林大学医学部 第一内科学教室

西端友香 ${ }^{1}$, 東 里緒 $^{1}$, 益田紗季子 ${ }^{1}$, 中沢大悟 ${ }^{2}$, 田中 敏 ${ }^{3}$, 外丸詩野 ${ }^{4}$, 中林公正 ${ }^{5}$, 石津明洋 ${ }^{1}$

抗 GBM 病の抗 GBM が認識するエピトープは, IV 型 コラーゲンの $\alpha 3$ 鎖非コラーゲン領域 $\alpha 3$ (IV) $\mathrm{NC} 1$ に存 在し，NC1 ドメインが六量体を形成することにより通常 は立体構造的に隔絶された状態である。我々は抗 GBM 病の標準治療に対して治療抵抗性を示し，再発を繰り 返す症例を経験した。本研究では，頻回再発症例（RR） の抗 GBMが認識するエピトープについて，非再発症例 （SA1〜SA4）を対照として，健常ヒト腎のホルマリン 固定パラフィン包埋（FFPE）切片を用いた免疫組織化 学とリコンビナント $\alpha 3$ （IV） NC1を用いたwestern blotting（WB）により検討した。酸性熱処理により切片上 に表出させた $\mathrm{GBM}$ 抗原に対する患者 $\mathrm{IgG}$ の反応性を検 討したところ，RRと SAでは陽性像のパターンが一部 異なり，RRの抗GBMはSAとは異なるエピトープを認 識していると考えられた。 $\alpha 3$ (IV) NC1を電気泳動し, $\mathrm{RR}$ の IgGをプローブとしたWBでは， wholeの $\alpha 3$ (IV) $\mathrm{NC} 1$ よりも小さな分子量のバンドも検出された。このバ ンドは $\alpha 3$ （IV） NC1のプロテアーゼ処理の有無に関わ らず検出された一方，同メンブレンを抗 $\alpha 3$ (IV) $\mathrm{NC1}$ モノクローナル抗体でリプローブした際には検出されな かった。RRの血清中にはNC1 ドメインの六量体結合が はずれるだけでは表出せず，NC1自体の立体構造が崩れ た時に初めて表出するエピトープに対する抗体が産生さ れている可能性が考えられる。このような抗体の出現が 治療抵抗性に関連している可能性が考えられる。

\section{III-2．焱症と線維化を反映した膠原病性肺高血圧症 マウスモデル作製の試み}

${ }^{1}$ 国立循環器病研究センター 研究所 血管生理学部, 2 大阪大学大学院医学系研究科 呼吸器·免疫内科学, 
${ }^{3}$ 国立循環器病研究センター 研究所 肺高血圧症先端 医学研究部, ${ }^{4}$ 国立循環器病研究センター 病理部

森 啓悦 ${ }^{1,2}$, 稲垣薰克 ${ }^{1}$, 石橋知彦 ${ }^{1}$, 岡澤 慎 $^{1}$, 正木 豪 $^{1}$, 浅野遼太郎 ${ }^{3}$, 大郷 剛 $^{3}$, 大郷恵子 ${ }^{4}$, 植田初江 ${ }^{4}$, 熊ノ郷淳 ${ }^{2}$, 中岡良和 ${ }^{1}$

\section{III-3. 冠動脈プラークのMRIT1強調画像高信号とプ ラーク内出血の関連}

1 宮崎大学医学部病理学講座構造機能病態学分野, 2 社会医療法人同心会古賀総合病院 放射線技術部 山下 篤 ${ }^{1}$, 黑岩靖淳 ${ }^{1,2}$, 内田暁子 ${ }^{1}$, 浅田祐士郎 ${ }^{1}$

III-4. 静脈血栓の病理組織像と拡散強調磁気共鳴画像 1 宮崎大学医学部病理学講座 構造機能病態学分野, 2 古賀総合病院 放射線技術部, 3 宮崎大学農学部 獣医 学科 獣医臨床放射線学研究室

魏 峻洸 ${ }^{1}$, 山下 篤 ${ }^{1}$, 黑岩靖淳 ${ }^{1,2}$, 小西祐子 ${ }^{3}$, 浅沼 武敏 ${ }^{3}$, 今村卓郎 ${ }^{2}$, 浅田祐士郎 ${ }^{1}$

【目的】深部静脈血栓の質的評価は, 抗血栓療法の 効果予測に重要であるが, 有用な画像診断法はまだ確 立されていない。核磁気共鳴画像 (MRI) の拡散強調 像（diffusion-weighted image: DWI）は静脈血栓（venous thrombus: VT）の質的な評価手法として期待されている が, 画像と病理組織像との対比は報告されていない。本 研究では, 家兔のVTモデルを用いて, VTのDWIと病 理組織像を比較検討した。【方法】家兔澒静脈にVTを 作成，経時的（4時間，1, 2, 3 週）にMRIを撮像し，組 織像との対比を行った。またヒト静脈血を用いて全血, 多血小板血漿, 多赤血球血を作成し, in-vitro MRI撮像 を行った。【結果】家兔VTのMRI像は，4時間後はDWI 高信号, ADC 低值を呈し, 1,2,3 週後ではDWIは等〜低 信号，ADCは高值を示した。組織学的には，4時間で赤 血球，フィブリン，血小板が主体の新鮮血栓で， 1,2 週 後で壁在部の器質化が, 3 週後では線維性組織への置換 が観察された。DWI信号強度は, 赤血球の面積率と正 の相関を示し, 筋線維芽細胞, マクロファージ，へモジ デリン，膠原線維の面積率と負の相関を示した。In-vitro MRIでは, 多赤血球血液でADC低值を呈する傾向が見 られた。【結語】VTにおけるDWI高信号やADC低值は 赤血球に富む新鮮な血栓を反映することが示唆された。
セッションIV'小血管病変と疾患'

座長: 池田栄二（山口大学大学院医学系研究科病 理形態学講座)

座長：倉田美恵（愛媛大学大学院医学系研究科 解 析病理学・愛媛大学プロテオサイエンスセン ター 病理学部門)

\section{IV-1. 好中球細胞外トラップの制御異常とANCA関 連血管炎}

北海道大学大学院保健科学研究院 病態解析学分野 石津明洋

好中球細胞外トラップ（NETs）は感染防御に不可欠 な自然免疫機構であるが, NETsの制御異常は, 生体内 にNETsの蓄積をもたらし，NETs成分に対する自己抗体 （ANCA はそのひとつである）産生や血管内皮障害の原 因となることが報告されてきた。NETs 制御異常が生じ る原因として，NETs 自体に生理的な NETs 分解因子であ るDNase I に対する抵抗性が付与される場合と血漿中の DNase Iの活性が低下する場合がある。前者は抗甲状腺 薬プロピルチオウラシル（PTU）服用時に認められ，後 者はAAV患者やSLE患者に認められる。PTUにより誘 導されるDNase I抵抗性 NETs の形成を Cl-amidine（NETs 形成時に作用する peptidylarginine deiminase の阻害剂）で 阻止することにより，ANCAの産生は抑制された。ま た，若齢に比べてDNase I活性の低下した高齢ラットに NETs を経静脈的に注射すると，血管壁にフィブリノイ ド壊死を伴う壊死性血管炎が誘導された。これらの結果 は, NETs の制御異常が AAVの病態形成に重要な役割を 果たしていることを示している。

\section{IV-2. 神経系血管バリアー機能異常と疾患} 山口大学大学院医学系研究科病理形態学講座 池田栄二

\section{IV-3． 脳小血管病の分子病態機序}

新潟大学脳研究所臨床神経科学部門 神経内科学分野 小野寺理 
セッションV 症例検討（血管炎病理診断コンサル テーション症例より)'

座長: 石津明洋（北海道大学大学院保健科学研究院 病態解析学分野)

\section{V-1. 血管焱病理診断コンサルテーションシステム の概要}

北海道大学大学院保健科学研究院 病態解析学分野 石津明洋

\section{V-2. 供覧症例：40歳, 女性, 脳生検}

山口大学大学院医学系研究科 病理形態学講座 池田栄二

\section{V-3. 供覧症例：59歳，男性，肺生検}

東邦大学医療センター大橋病院 病理診断科 高橋 啓

セッションVI

座長：高橋 啓（東邦大学医療センター大橋病院 病理診断科)

VI-1. 川崎病及び血流負荷における動脈拡張は「折 りたたまれた陰窩」の中で始まる一仮説的考察

${ }^{1}$ 雄勝中央病院 検査科病理, ${ }^{2}$ 秋田大学大学院医学系研 究科 器官病態学講座

増田弘毅 ${ }^{1}$, 伊藤行信 ${ }^{2}$, 吉田 誠 $^{2}$, 後藤明輝 ${ }^{2}$

動脈拡張は臨床的に川崎病で，実験的に血流負荷動脈 リモデリングで観察される。川崎病動脈の拡張スピード は速く生物学的リモデリングで生じていると考えるより も，何か物理的な構造転換が生じていると考えた方が論 理的である。一般的に壁の壊死崩壊が要因とされている が，観察する限りほとんど生じていない。この転換の 一つの考方方として「折りたたまれた陰窩」仮説を提案 する。川崎病発症により内在する小さい「折りたたまれ た陰窩」で拡張の準備が始まり，発症10日にかけて梁 くなり，さらに大きく深くなり闇值を超えた症例におい て「陰窩」が解放されて急速に搪張するという考え方で ある。一方血流負荷による動脈拡張実験では血流負荷 4 週に約 2 倍の太さになる。この時の内腔の形態は規則的 で，本来の内腔面が碁盤の目状に断裂する。断裂した場 所には新しく広がった内腔面が出現する。この形態は規 則的に内在する「折りたたまれ陰窩」が活性化し解放さ
れた状態と考えることができる。川崎病においても血流 負荷リモデリングにおいても，動脈拡張は「折りたたま 机陰窩」の活性化であると考えることができる。

\section{VI-2. 川崎病大動脈の筋型動脈への移行部における 組織学的検討}

東邦大学医療センター大橋病院 病理診断科

佐藤若菜, 横内 幸, 大原関利章, 榎本泰典, 高橋 啓

【目的】川崎病は主に中小型血管が障害される。前回 の本会では，大動脈にもマクロファージ $(\mathrm{M} \Phi)$ 主体の 炎症が生じていることを報告した。今回は大動脈基部, 肋間動脈など筋型動脈分岐部近傍の大動脈について，分 岐を含まない胸腹部大動脈と比較し組織学的に検討し た。【方法】川崎病剖検例のうち, 大動脈基部と胸腹部 大動脈の検索が可能であった 12 例（急性期 6 例，遠隔期 6 例）, 分岐部大動脈と胸腹部の検索が可能であった 8 例 （急性期 4 例，遠隔期 4 例）を対象とした。免役染色を 用いて，大動脈壁各層における炎症細胞数を計測した。 【結果】《急性期》基部では胸腹部と比較して外膜におけ る炎症細胞浸潤が目立った。また, 分岐部大動脈も胸腹 部と比較して外膜に炎症細胞浸潤が強い傾向を示した。 また， 1 例は筋型動脈分岐直後に瘤を形成しており，大 動脈から筋型動脈に移行する部分に特に多くの炎症細胞 浸潤をみた。《遠隔期》全例に打いて炎症はそしかった。 【まとめ】分岐部近傍の大動脈は分岐を含まない胸腹部 大動脈と比較して炎症が高度である傾向がある。

\section{VI-3. 突然死の剖検 3例における心筋梗塞の有無の 判定：冠動脈平滑筋の免疫染色の有用性}

${ }^{1}$ 東京医科大学 分子病理学分野, ${ }^{2}$ 東京医科大学病院 整形外科, ${ }^{3}$ 東京医科大学病院 循環器内科, ${ }^{4}$ 東京医科 大学病院 安全管理室

倉田 厚 $^{1}$, 西田 淳 $^{2}$, 小山尊士 ${ }^{2}$, 齋藤哲史 ${ }^{3}$, 三木 保 ${ }^{4}$, 山科 章 $^{3}$, 黑田雅彦 ${ }^{1}$

【背景】突然死の剖検において，急性心筋梗塞の有無 判定は重要であるが，心筋の壞死は発症後3〜6時間経 たないと判然としない。我々が近年, 剖検例の検索か ら提言している, 冠動脈内膜平滑筋の未熟度と心筋梗 塞をもたらすプラーク不安定化との相関が、こうした剖 検診断で有用かを検討した。【対象と経過】3例の剖検 例を対象とした。症例 1 は糖尿病の既往のある60歳男 性, 足関節の脱臼骨折の手術後 7 日目, 病棟にて心肺停 
止。症例 2 は関節リウマチの既往のある 75 歳女性，転倒 にて左大腿骨近位部の骨折, 観血的整復固定術の帰室 後 1 時間で急変し心肺停止。症例 3 は 78 歳女性, 自宅で 転倒し心室粗動，救急搬送され，翌日，死亡となった。 【剖検結果】症例 1 では冠動脈狭窄高度, PTAH染色にて 心筋にわずかに横紋の消失がみられた。症例 2 では冠動 脈狭窄軽度，心筋の変化は乏しく，肺動脈内に脂肪塞 栓の多発を認めた。症例 3 では左心室前壁に $2.5 \times 1.5 \mathrm{~cm}$ 大の壊死巣を認めた。冠動脈内膜平滑筋の h-caldesmon/ $\alpha$-SMA 陽性比率は症例 1 で $10 \%$ 未満，症例 2 で約 50\%, 症例 3 で約 $10 \%$ であった。【結論】症例 1 と 3 は急性心筋 梗塞，症例 2 は肺脂肪塞栓で死亡したと考えられた。 $\mathrm{h}$ caldesmon/ $\alpha$-SMA 陽性比率で示される内膜平滑筋成熟度 は，プラークの安定化に関わり，突然死の剖検例での検 討でのプラーク破綻から来る心筋梗塞発症の有無の傍証 となると示唆された。

\section{VI-4. ヒストンは好中球細胞上にLAMP2を表出し， 抗LAMP2抗体と連携して皮膚小血管炎の発 症機序に関与している}

${ }^{1}$ 東北医科薬科大学 皮膚科, ${ }^{2}$ 聖マリアンナ医科大学 皮膚科, ${ }^{3}$ 北海道大学大学院保健科学研究院 病態解析学 分野, ${ }^{4}$ 北海道大学大学院医学研究院 分子病理学教室 川上民裕 ${ }^{1}$, 竹内之ら ${ }^{2}$, 菊池彩翔 ${ }^{3}$, 西端友香 ${ }^{3}$, 益田紗 季子 ${ }^{3}$, 外丸詩野 ${ }^{4}$, 石津明洋 ${ }^{3}$

【目的 1】抗LAMP2抗体単独で野生型ラット皮膚小 血管に好中球を集積させるとは考えにくく，ヒスト ン曝露を選択した。【方法1】野生型ラットに, Rabbit $\operatorname{IgG}$ のみ静注（Group1: 4匹），ヒストン+ Rabbit IgG 静 注 (Group2: 5 匹), 抗LAMP2 抗体静注 (Group3: 4匹), ヒストン+抗LAMP2 抗体静注（Group4: 5 匹）の4通り で注射した。3日後, 剖検し, 皮膚小血管への好中球 浸潤の数を指標として，4群を比較検討した。【結果 1】 Group4は, Group1 と有意差, Group2 と有意差を認めた。 Group3は, Group1・Group2・Group4 と有意な差はな かった。Group4は，大脳や心臓など皮膚以外の臟器で は血管に好中球誘導は見られなかった。【目的2】ヒス
トン曝露により，ヒト好中球細胞表面上にLAMP2が発 現誘導されるかを検証した。【方法2】健常人末梢血採 取から好中球を獲得した。ヒストン刺激を行った後，抗 LAMP2 抗体 (Rabbit IgG)/Control Rabbit IgG, 蛍光標識 anti-rabbit IgGを経てフローサイトメトリーで測定した。 【結果 2】ヒストン曝露で濃度依存性・時間依存性にヒ 卜好中球細胞表面にLAMP2が表出された。【考察】すで に皮膚血管炎の症例で血中抗LAMP2抗体が上昇するこ とを報告している。ヒストンによる初期の刺激が，好中 球細胞表面にLAMP2 表出し, 抗LAMP2 抗体と協調し て皮膚小血管に好中球を集積させるメカニズムを推測し た。

\section{VI-5. 皮膚血管炎の病理像による主要臟器のリスク 予測の検討}

1 吳医療センター・中国がんセンター 総合診療科, ${ }^{2}$ 総 合病院山口赤十字病院 臨床研修部, ${ }^{3}$ 山口大学大学院 医学系研究科 病理形態学講座 中村浩士 ${ }^{1}$, 三國雅倫 ${ }^{2}$, 池田栄二 ${ }^{3}$

皮膚組織に打ける血管炎（Chapel Hill分類；小）が, 将来の内臓病変や血管炎（Chapel Hill分類；小～大）を 予期することが可能か否かを，過去の皮膚血管炎の組織 標本の病理所見と, 臨床情報を比較することで検討し た。1989年から 1999 年の期間内で, 山口大学附属病院 病理組織診断にて, 血管炎と判断された患者のべ53名 を対象とした。対象患者の病理組織像をHE染色, 免疫 染色を用いて評価した。2014年 8 月現在の主要臟器の評 価は, 電子カルテにて行い, 病名, 疾患臓器障害とその 程度，血管炎（Chapel Hill分類；小～大）の有無を調査 した。血管周囲のフィブリン析出は, CRP值とは負の相 関を，赤血球数とは正の相関を示した $(\mathrm{p}<0.05)$ 。好中 球浸潤と，ALT值とプレドニンの使用量が正の相関を示 した $(\mathrm{p}<0.05)$ 。さらに, 赤血球遊出と多関節痛の出現 も有意であった（ $\mathrm{p}<0.01 ）$ 。皮虐組織に打ける血管炎の 病理所見は, 将来の主要藏器の疾病のうち, 特に内臟血 管炎を予測しうる可能性が示唆された。 